\title{
ZASTOSOWANIE TEORII PROGOWEJ MALISZA DO PROGNOZOWANIA PRZEMIAN PRZESTRZENI TURYSTYCZNEJ W ŚWIETLE CYKLU ŻYCIA OBSZARU TURYSTYCZNEGO (TALC) BUTTLERA ORAZ ETAPÓW ROZWOJU PRZESTRZENI TURYSTYCZNEJ WEDŁUG LISZEWSKIEGO I WŁODARCZYKA
}

\begin{abstract}
1. Wstęp
Celem niniejszej pracy jest wskazanie możliwości zastosowania metody analizy progowej Malisza i Kozłowskiego do prognozowania przekształceń miejscowości i obszarów turystycznych, dzięki czemu możliwe jest wyznaczenie progów rozwoju przestrzeni turystycznych według Liszewskiego (asymilacja, kolonizacja, urbanizacja) i Włodarczyka (przestrzeń nowa, dojrzała, stara). Wskazano także możliwość ustalania wielkości progowych przebiegu wykresu cyklu życia obszaru turystycznego (TALC) według Buttlera. Autor podkreśla rolę mierników i wskaźników urbanistycznych oraz analizy kosztów działań inwestycyjnych adaptowanych na potrzeby prognozowania możliwości przemian i zagospodarowania przykładowej przestrzeni turystycznej.
\end{abstract}




\section{Przemiany przestrzeni turystycznej oraz cykl życia obszaru turystycznego}

Przestrzeń turystyczna według S. Liszewskiego jest „funkcjonalnie wyróżniającą się częścią (podprzestrzenią) przestrzeni rozumianej w sensie largo, tzn. jako przestrzeń, na którą składają się elementy przyrodnicze powłoki Ziemi (środowisko naturalne), trwałe efekty działalności ludzkiej w tym środowisku (środowisko gospodarcze), a także środowisko człowieka w rozumieniu społecznym" (LISZEWSKI 1995). Wyróżnić tu można pięć podstawowych rodzajów przestrzeni turystycznej wraz ze wskazaniem realizowanej w nich działalności turystycznej:

- przestrzeń eksploracji turystycznej (odkrywanie nowych obszarów na potrzeby wprowadzenia działalności turystycznej przy względnie małej skali rozwijanego ruchu turystycznego);

- przestrzeń penetracji turystycznej (realizacja celów poznawczych, krajoznawczych i wypoczynkowych bez noclegów o dość dużej intensywności ruchu turystycznego);

- przestrzeń asymilacji turystycznej (czasowy pobyt turystów i ich integracja $\mathrm{z}$ otoczeniem $\mathrm{z}$ zapewnieniem noclegów przy zachowaniu dużej intensywności ruchu turystycznego);

- przestrzeń kolonizacji turystycznej (zagospodarowywanie terenów przez nowe obiekty turystyczne, co prowadzi do dominacji funkcji turystycznej o bardzo dużej intensywności);

- przestrzeń urbanizacji turystycznej (na obszarach skolonizowanych turystycznie następuje rozwój stałego osadnictwa miejskiego i zamieszkania ludności, przy jednoczesnych wahaniach wielkości ruchu turystycznego - wówczas następuje stabilizacja jego wielkości lub ma miejsce zmniejszenie skali ruchu turystycznego).

Badania procesów przekształceń i rozwoju funkcji turystycznych prowadzone są $\mathrm{w}$ przestrzeni turystycznej, gdzie występuje ruch turystyczny (WŁODARCZYK 2009). W ramach przestrzeni turystycznej można wyróżnić następujące elementy składowe: dziedzictwo przyrodnicze, dziedzictwo kulturowe, infrastrukturę (techniczną, społeczną, gospodarczą) oraz działalność człowieka. Jedynym niezbędnym elementem $\mathrm{w}$ przestrzeni turystycznej jest zawsze człowiek, gdyż to on kreuje przestrzeń i z niej korzysta, realizując różnorodne formy działalności turystycznej, gdzie elementem dodatkowym może być jakakolwiek dowolna forma przestrzeni fizycznej będąca obiektem 
zainteresowania turystycznego. Przestrzeń turystyczna w dowolnej skali bez użytkującego ją człowieka według S. LISZEWSKIEGO (2005) i B. WŁODARCZYKA (2009) nie istnieje. Potwierdzają to także inni badacze tej problematyki (DURYDIWKA 2011).

Działalność człowieka ma charakter z natury dynamiczny, a zatem jego działania w przestrzeni turystycznej wprowadzają dynamizm w jej istnieniu. Przestrzeń turystyczna, w której pojawia się człowiek, niezależnie od jej rodzaju, podlega dynamicznym zmianom i przekształceniom. Przekształcenia przestrzeni turystycznej są zwykle kreowane przez właścicieli terenów zaliczanych do przestrzeni turystycznej pod wpływem użytkujących ją uczestników ruchu turystycznego. Gdy właściciel - dysponent przestrzeni geograficznej - zamyka ją przed dostępem dla uczestników ruchu turystycznego, wówczas obszar taki przestaje być automatycznie przestrzenią turystyczną, gdyż odtąd nie ma tam osób określanych jako turyści.

Właściciel dowolnego obszaru (nieruchomości niezabudowanej lub zabudowanej), zgodnie z prawami gospodarki rynkowej, z reguły dąży do podniesienia wartości majątku, jaki posiada i osiągnięcia korzyści z tego wynikających. Dysponent przestrzeni przedturystycznej, zgodnie z prawem popytu i podaży, w przypadku pojawienia się osób, organizacji, instytucji czy władz zainteresowanych ruchem turystycznym, zwykle podejmuje działania zmierzające do uzyskania dodatkowych korzyści wynikających z jego wkroczenia. Faktyczne pojawienie się turystów w takim miejscu tworzy z tego obszaru przestrzeń turystyczną rozwijaną (przekształcaną), począwszy od jej odkrycia przez turystów (gdy turyści wkraczają pierwszy raz na taki obszar), aż do zakończenia „życia” przestrzeni turystycznej (gdy ostatecznie turyści ją opuszczają). W praktyce, jak już raz ruch turystyczny wkroczył na dany teren i powstaje przestrzeń turystyczna, to nawet najbardziej niesprzyjające warunki środowiskowe są eksplorowane przez turystów (np. zwiedzanie ruin nieczynnej elektrowni atomowej w Czarnobylu czy Fukushimie w ubraniach chroniących przed promieniowaniem). Jest to turystyka ekstremalna, wymagająca specjalnych kwalifikacji, a nie powszechnie spotykana forma niewykwalifikowanej turystyki masowej. Przekształcenia, o których można zatem mówić, potwierdzają wniosek, że zawsze istniała przestrzeń przedturystyczna (praturystyczna), a następnie przestrzeń turystyczna. W ostateczności może zaistnieć przestrzeń poturystyczna (postturystyczna), która po upływie dowolnego okresu może powtórnie przeobrazić się w przestrzeń przedturystyczną (praturystyczną), w ramach której rozpatrywane jest wprowadzenie funkcji turystycznej. Granicę między przestrzenią 
poturystyczną i przedturystyczną wyznacza subiektywne zainteresowanie tym obszarem przez turystów oraz moment podjęcia prawnej decyzji, że turystyka może powtórnie wkroczyć na dany obszar. Proces przekształceń może mieć zatem charakter ciągły i faktycznie tworzy zamknięty cykl przemian (kontinuum) szeroko rozumianej przestrzeni geograficznej (WŁODARCZYK 2009).

Przykładem takiego kontinuum są tereny jednostki wojskowej Marynarki Wojennej w Kołobrzegu gdzie do 1829 roku była przestrzeń przedturystyczna, a w latach 1829-1945 park Maikuhle był kluczową wypoczynkową przestrzenią turystyczną Kołobrzegu. Po II wojnie światowej teren zamknięto, budując jednostkę wojskową i 19. Baterię Artylerii Stałej (BAS) lądowej obrony wybrzeża, przez co obszar ten stał się przestrzenią postturystyczną. Podjęta w 2012 roku eksploracja muzealników i członków stowarzyszeń turystyki militarnej oznaczała zamianę tego terenu na przestrzeń przedturystyczną, na którą w ciągu kilku lat wkroczy ruch turystyczny. Obszar ten formalnie stał się przedturystycznym w 2014 roku, po przekazaniu go przez Marynarkę Wojenną dla Muzeum Obrony Wybrzeża w Świnoujściu, które z kolei udostępni go dla turystów, tworząc powtórnie przestrzeń turystyczną o funkcji spacerowo-muzealnej.

Rozważania licznych autorów badań przestrzeni turystycznej poparte przykładem obszaru 19. BAS w Kołobrzegu wskazują na występowanie kilku cykli rozwoju przestrzeni:

1) przestrzeń przedturystyczna (praturystyczna), gdzie nie ma funkcji turystycznej i ruchu turystycznego, ale są zasoby i być może wola „właściciela" danego terenu, by rozwinąć tam przestrzeń turystyczną i wprowadzić ruch turystyczny;

2) przestrzeń turystyczna na różnych etapach rozwoju (według S. Liszewskiego): eksplorowana, penetrowana, asymilowana, kolonizowana, urbanizowana), w trzech fazach (wg B. Włodarczyka) jako:

a) „nowa” (dopiero odkryta, gdzie wprowadzane są nowe funkcje turystyczne),

b) „dojrzała” (gdzie, jak należy sądzić, preferowaną formą użytkowania jest możliwie długotrwałe „optymalne” wykorzystanie i rozwój funkcji turystycznej),

c) „stara” (po długotrwałym wykorzystaniu, gdy następuje wyeksploatowanie walorów przyrodniczych i antropogenicznych oraz postępuje degradacja szeroko rozumianej infrastruktury technicznej, społecznej, gospodarczej itp.);

94 WARSZTATY Z GEOGRAFII TURYZMU 
3) przestrzeń poturystyczna „postturystyczna” (gdy przestrzeń przestała już pełnić funkcje turystyczną, a ruch turystyczny na jej obszarze zanikł - WŁODARCZYK 2011); przestrzeń ta jest całkowicie zamknięta dla ruchu turystycznego, a w przypadku podjęcia decyzji o jej użytkowaniu turystycznym może stać się formalnie przestrzenią przedturystyczną.

Na szczególną uwagę w badaniach zasługuje przestrzeń turystyczna na etapie kolonizacji turystycznej (LISZEWSKI 2005), zwłaszcza na optymalnym poziomie rozwoju - w fazie dojrzałej (WŁODARCZYK 2011) i na początkowym etapie stagnacji $w$ ramach cyklu życia obszaru turystycznego (BUTTLER 1980, 2011), ale jeszcze przed rozpoczęciem procesu reorientacji (BUTTLER 2011, AGARWAL 2002). Wspomniani badacze zauważają, że w którymś momencie rozwoju, etapie czy cyklu życia przestrzeni turystycznej (obszaru turystycznego), pojawiają się zjawiska wskazujące na osiągnięcie „szczytu rozwojowego" przestrzeni, etapu czy cyklu życia, jaki można wyznaczyć.

Skutkiem osiągnięcia umownego „szczytu rozwoju” dla określonego analizowanego cyklu czy fazy funkcjonowania przestrzeni turystycznej jest zwykle podejmowanie działań zmierzających do przedłużenia trwania ",szczytu rozwojowego" (AGARWAL 2002). Wiąże się to zazwyczaj z bardzo kosztownymi działaniami inwestycyjnymi, rewitalizacyjnymi, odmładzającymi, reklamującymi i promocyjnymi. Najważniejszym problemem sygnalizowanym przez wielu autorów jest wyznaczenie nadejścia tego kluczowego „momentu szczytowego", w sytuacji gdy faktycznie nie wiadomo, jak w dłuższym czasie dany obszar turystyczny będzie się zmieniał. Należy się zgodzić, że przewidywanie przyszłego przebiegu TALC jest istotną słabością teorii Buttlera. W przypadku jej etapów (Liszewski) czy faz rozwoju (Włodarczyk) brak jest mierzalnych wskazań, kiedy został osiągnięty określony etap czy cykl rozwoju, a od kiedy można uznać, że np. zamiast procesów kolonizacji turystycznej przewagę zyskują procesy urbanizacji turystycznej - poza ogólnym wskazaniem, że np. przewagę ma powierzchnia użytkowa realizowanych inwestycji mieszkaniowych czy apartamentowych, albo dominować zaczyna pojemność bazy noclegowej według pobytu czasowego (np. hotele) lub stalego (apartamenty). A zatem ustalenie skali, kierunku i przebiegu przemian przestrzeni turystycznej, choćby w bliskiej przyszłości, staje się absolutnie kluczowe, a dotychczasowe opracowania mało precyzyjnie określają zakończenie i przejście do kolejnej fazy czy etapu przemian przestrzeni turystycznej. 


\section{Teoria progowa jako narzędzie analiz przestrzennych i funkcjonalnych}

Badania nad rozwojem miast i sieci osadniczych prowadzone w latach 70 . XX wieku przez B. MALISZA (1971) potwierdzily, że w procesie planowania obszarów miejskich należy sięgać do stworzonej przez niego metody analizy progowej czy koncepcji układu pasmowo-węzłowego (DZIEWOŃSKI 1980), $\mathrm{w}$ tym pasmowego $\mathrm{w}$ typowym osadnictwie nadmorskim.

Podjęcie próby zastosowania tej metody do problematyki wyznaczenia progów rozwojowych dla przestrzeni turystycznej wymaga wpisania jej do teorii TALC (w dowolnym momencie cyklu), do etapów rozwoju przestrzeni turystycznej (szczególnie dla etapów asymilacji, kolonizacji i urbanizacji turystycznej według Liszewskiego) lub do cykli rozwoju (zwłaszcza cyklu rozwoju przestrzeni przedturystycznej na etapie planowania powstania przestrzeni turystycznej), a także do wszystkich trzech faz rozwoju przestrzeni turystycznej (tzn. nowej, dojrzałej i starej według Włodarczyka).

Punktem wyjścia do ustalenia poziomów progowych rozwoju przestrzeni turystycznej powinno być podobnie jak w urbanistyce wydzielenie takich mierników zagospodarowania przestrzennego analizowanego obszaru (przestrzeni turystycznej lub przedturystycznej), które mają lub będą miały decydujący wpływ na rozwój, a jednocześnie są łatwe do wyznaczenia i skwantyfikowania. Mierzalne efekty powinny być również łatwe do ustalenia, a kluczowe jest wyznaczenie akceptowalnych kosztów inwestycji, jakie należy ponieść $\mathrm{w}$ związku z powstaniem przestrzeni turystycznej lub osiągnięciem określonego poziomu rozwoju danej przestrzeni turystycznej (w kontekście opłacalności inwestycji czy założeń teorii lokalizacji inwestycji, gdy inwestycja powinna być optymalna, a jest najczęściej zadowalająca ekonomicznie). Możliwe jest także wyznaczenie progów rozwojowych dla procesów rewitalizacji czy odmłodzenia przestrzeni turystycznej, a w skrajnym przypadku progowych kosztów likwidacji przestrzeni turystycznej (zamknięcia danego obszaru przed jakąkolwiek eksploatacją turystyczną) czy powtórnego odtworzenia przestrzeni turystycznej. Poniesione nakłady mogą być niezależne od lokalizacji inwestycji (zależne jedynie od cech budowanych obiektów) lub zależne od istotnych cech danego terenu (nawodnienie, geologia itp.). Wyróżnia się również progi terenowe (wynikające $\mathrm{z}$ warunków fizycznogeograficznych obszaru), progi strukturalne (wynikające ze struktury istniejącego zagospodarowania i użytkowania terenów) oraz progi

96 WARSZTATY Z GEOGRAFII TURYZMU 
ilościowe (wynikające z możliwości rozwoju miasta pod względem wielkościowym, tj. infrastruktura, sieci, przepustowość, odległości itp.).

Podczas przeprowadzania analizy progowej przemian przestrzeni turystycznej w rozwoju przestrzennym i zaludnienia (liczby turystów i odwiedzających) można wyróżnić istotne ograniczenia, których źródłem są:

- zróżnicowanie fizjograficzne terenu (ograniczenia fizycznogeograficzne);

- układ użytkowania terenu (ograniczenia funkcjonalne);

- techniczne ograniczenia infrastrukturalne (ograniczenia technologiczne);

- możliwości przebudowy strukturalnej (ograniczenia strukturalne) (EBERDHARD 1980).

Wzrost liczby ludności oraz skali procesów inwestycyjnych wymusza pozyskiwanie nowych terenów zainwestowanych, co skutkuje przekraczaniem progów terenowych, a tym samym, w większości przypadków, progów strukturalnych i ilościowych. W wyniku tego silnie rosną koszty w stosunku do normalnego „dogęszczania” czy optymalizacji wykorzystania terenów już wcześniej zainwestowanych. Poniesione znacznie wyższe niż przeciętnie koszty umożliwiają pozyskanie nowych terenów inwestycyjnych, a ostateczny efekt przekroczenia progu rozwojowego może być oceniony poprzez wskaźniki chłonności mierzone np. liczbą ludności, pojemnością bazy noclegowej czy liczbą przewidywanych miejsc pracy.

Wyróżnić można również progi skokowe (jednorazowe koszty przekroczenia bariery, np. rzeki), progi stopniowe (koszty rosną stopniowo w miarę zagospodarowywania danego obszaru) oraz progi złożone, gdy oba powyższe progi należy pokonywać jednocześnie na tym samym obszarze i w tym samym czasie (EBERDHARD 1980).

Podejmując działania zmierzające do okeślenia, w jaki sposób wyznaczyć przebieg perspektywicznych przemian przestrzeni turystycznych zwykle sięgamy do tzw. zamierzeń inwestycyjnych i na podstawie planów inwestycyjnych podejmujemy próbę ustalenia dalszych kierunków rozwoju badanego obszaru. W analizie progowej należy dążyć do określenia ograniczeń progowych, a następnie kosztów niezbędnych do ich przezwyciężenia (EBERHARD 1980). Porównanie kosztów prowadzi do wyboru wariantu rozwoju przestrzeni turystycznej.

Podobnie jak teoria progowa rozwoju miast teoria progowa rozwoju przestrzeni turystycznej powinna uwzględniać podstawowe koszty i parametry rozbudowy infrastruktury turystycznej niezbędnej do powstania 
i funkcjonowania na określonym poziomie przestrzeni turystycznej, a także rozbudowy funkcji turystycznych $\mathrm{w}$ przestrzeni turystycznej czy przedturystycznej. Oczywiście ocena kosztów jest pojęciem względnym.

Przykładowymi miernikami i wskaźnikami dla określania możliwości przemian dla obszaru przestrzeni turystycznej czy przedturystycznej o powierzchni np. 10 ha $\left(100000 \mathrm{~m}^{2}\right)$ mogą być:

- przewidywana wycena nieruchomości wykorzystywanych do celów turystycznych, np. $400 \mathrm{zl} / 1 \mathrm{~m}^{2}$ przy powierzchni łącznej terenu 10 ha - wówczas wartość terenu wynosi $40 \mathrm{mln}$ zł;

- przewidywana chłonność turystyczna określonego obszaru przestrzeni turystycznej przy określonych zasobach środowiskowych i zastrzeżeniu przestrzegania założenia ochrony walorów turystycznych z zachowaniem zasad zrównoważonego rozwoju, np. chłonność 5000 osób i wycena istniejących walorów oraz zasobów środowiskowych $\mathrm{m}$.in. na kwotę $10 \mathrm{mln}$ zł (łącznie z ogólną ceną $50 \mathrm{mln}$ zł). Przy założeniu zwiększenia chłonności o 500 osób (10\%) następuje wzrost wartości terenu i kosztów ochrony zasobów oraz walorów środowiska o kolejne $10 \mathrm{mln} \mathrm{zł}(+20 \%)$;

- ustalenie przewidywanej średniej liczby miejsc noclegowych (dalej: m.n.), np. 500-600 m.n./1 ha, co oznacza średnią wysokość zabudowy określaną na pięć kondygnacji (na terenie o powierzchni 1ha, powierzchnia zabudowy $25 \%$, powstają trzy budynki 5-kondygnacyjne o łącznej powierzchni użytkowej (dalej: p.u.) około $11250 \mathrm{~m}^{2}$, z tego powierzchnia użytkowa mieszkalna (dalej: p.u.m.) może sięgnąć około $80 \%$ powierzchni użytkowej budynków, co daje blisko $9000 \mathrm{~m}^{2}$ p.u.m. Przy założeniu średniej powierzchni apartamentu na poziomie około $30 \mathrm{~m}^{2}$ możliwe jest ulokowanie tam około 300 apartamentów na 600 m.n., a cały teren będzie miał pojemność około 5000-6000 miejsc noclegowych;

- intensywność zabudowy, tj. wskaźnik określający stosunek sumy ogólnej powierzchni zabudowy do powierzchni terenu, np. 25\%, czyli pod zabudowę może być przeznaczone 0,25 ha $\left(2500 \mathrm{~m}^{2}\right)$ terenu przy jego ogólnej powierzchni $10000 \mathrm{~m}^{2}$ (1 ha);

- wskaźnik powierzchni zabudowy przestrzeni turystycznej - suma powierzchni wszystkich kondygnacji budynków o funkcjach turystycznych na danym terenie liczona w zewnętrznym obrysie murów/ścian, np. pięć kondygnacji przy wskaźniku 1 (13 kondygnacji wskaźnik 1,5). Oznacza to, że budynek 5-kondygnacyjny zawiera powierzchnię użyt-

98 Warsztaty Z GEOGRAFII TURYZMu 
kową równą powierzchni terenu, natomiast 13-kondygnacyjny może tę powierzchnię przekroczyć 1,5-krotnie (przy założeniu powierzchni zabudowy terenu do poziomu $25 \%$ ), a zatem przy powierzchni zabudowy $25 \%$ terenu i wysokości pięciu kondygnacji możliwe jest osiągnięcie zagęszczenia około 600 osób/1 ha;

- koszt budowy miejsc parkingowych (dalej: m.p.), przy założeniu, że 1 m.p./1 pokój 2-osobowy - konieczność usytuowania na obszarze 1 ha 300 miejsc parkingowych, co przy zapotrzebowaniu $10 \mathrm{~m}^{2} / 1 \mathrm{~m} . \mathrm{p}$. daje około $3000 \mathrm{~m}^{2}$ tylko pod miejsca parkingowe. Niezbędna jest zatem realizacja części miejsc $\mathrm{w}$ formie parkingów podziemnych, co przy liczbie niezbędnych m.p. 300 oznacza konieczność budowy jednopoziomowego parkingu podziemnego pod budynkami $z$ łącznikiem i wjazdami między nimi, tak by zachować wymagane parametry wielkości terenów zielonych czy innych form użytkowania.

Niezbędne jest także uwzględnienie:

- kosztów budowy infrastruktury komunikacyjnej umożliwiającej dostęp i komunikację wewnątrz badanego terenu (drogi, chodniki, ścieżki rowerowe itp.) w przeliczeniu na 1 ha;

- kosztów budowy infrastruktury technicznej sieciowej i punktowej (wodociągi, kanalizacja, ciepłownictwo, energetyka, telekomunikacja $\mathrm{i}$ inne) w przeliczeniu na 1 ha;

- kosztów urządzonej zieleni i terenów sportowo-rekreacyjnych przy założeniu, np. 50-procentowego udziału terenów zielonych na obszarze analizowanej przestrzeni turystycznej, biorąc pod uwagę możliwość realizacji części zieleni w formie urządzonych terenów zielonych na dachach budynków, gdzie minimalna powierzchnia wynosi $10 \mathrm{~m}^{2}$, co stanowi równoważnik $20 \mathrm{~m}^{2}$ na poziomie zagospodarowywanego terenu;

- kosztów prac geologicznych, inżynierskich, budowlanych związanych z przekształceniem terenu pod funkcje turystyczne czy paraturystyczne, np. wiercenia geologiczne przed rozpoczęciem realizacji inwestycji w celu właściwego posadowienia budynków.

Zatem uwzględniając wszystkie koszty realizacji inwestycji oraz zagospodarowania terenu, a także koszty zakupu działki (nieruchomości) oraz zaplanowane przychody, można ustalić sens możliwości realizacji inwestycji czy przekształcania terenu, a tym samym podjąć decyzję, czy dane działanie będzie realizowane. Należy jednak zauważyć, że w celu analizy możliwości 
przemian i rozwoju przestrzeni turystycznej uwzględnienie większości powyżej wskazanych parametrów inwestycyjnych jest kłopotliwe, gdyż sytuacja rynkowa oraz ogromne zróżnicowanie zamierzeń inwestycyjnych sprawiają, że trudno mówić o kompleksowym planowaniu zagospodarowania przestrzeni turystycznej wyłącznie z punktu widzenia planowanych, projektowanych i realizowanych zadań inwestycyjnych. Na jednym terenie może być kilku inwestorów, a każdy z nich może planować swoje działania w co najmniej 2-3 wariantach. Opierając przewidywania rozwojowe tylko na wizjach inwestycyjnych, niestety nie mamy pewności, że zostaną one faktycznie zrealizowane i nie wiadomo ostatecznie, jakie parametry będą uwzględnione. W warunkach gospodarki centralnie planowanej lub przy realizacji inwestycji celu publicznego możliwe byłoby stosowanie analiz opłacalności wspomnianych inwestycji. W warunkach gospodarki wolnorynkowej i przy względnej stabilności zapisów MPZP najlepszym wyjściem jest jednak odwołanie się do klasycznej urbanistyki i zasad planowania przestrzennego. Dzięki temu preferowane kierunki zagospodarowania danego terenu są bardziej stabilne i określone $\mathrm{w}$ ramach dość precyzyjnych dokumentów planistycznych.

W ramach teorii progowej J. REGULSKI i S. WYGANOWSKI (1965) przyjęli, że analiza progowa wymaga badania przyrostu kosztów zainwestowania do przyrostu liczby mieszkańców. Dzięki takiemu założeniu wprowadzili pojęcie średniej wartości zainwestowania na mieszkańca. Jest to także syntetyczny wskaźnik standardu wyposażenia miasta, gdzie wartość zainwestowania średniego:

$$
Z s=\frac{Z p}{M},
$$

a zatem standard wyposażenia

$$
Z s=S w=\frac{Z p}{M},
$$

gdzie:

Sw - standard wyposażenia,

Zp - wartość zainwestowania,

$M$ - liczba mieszkańców.

Tak opracowany wskaźnik może być stosowany do porównań dla innych obszarów zainwestowanych, a co najważniejsze może być stosowany do porównań progowych przemian przestrzeni turystycznej w zakresie standardów jej zagospodarowania. 
Obecnie opracowywane miejscowe plany zagospodarowania przestrzennego zawierają porównywalne dane do faktycznie wykorzystywanych mierników i wskaźników urbanistycznych na potrzeby teorii progowej, co można przedstawić na przykładzie obecnie aktualizowanego miejscowego planu zagospodarowania przestrzennego (MPZP) Kołobrzeg-Wschód dla przykładowej jednostki przestrzennej 29 UZ (usługi zdrowia).

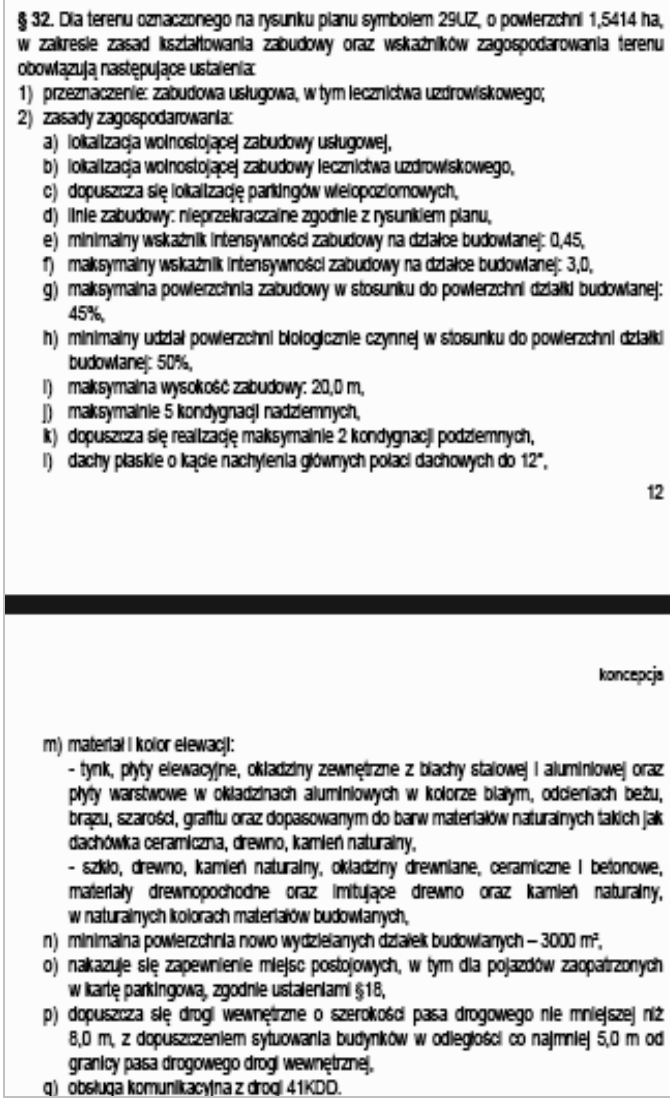
phyty warstwowe w okladzinach aluminiowych w kolorze blaym, odderlach betu, brazal, zarosd, grantu oraz dopasowarym do barw materiaiow naturainych takich jak dachouka ceramierna, dewno, karmien naturainy,

- satio, drewno, kamien naturainy, okiadziny drewniane, ceramiczne I betonowe, materlaky dresnopochodne oraz imitulape drewno oraz kamian naturainy, w naturalnych kolorach materiaiow budowarych,

n) minimaina powlerzchria nowo wydzlelanych dzalek budowarych $-3000 \mathrm{~m}^{2}$,

o) nakazyle slę zapeunienle miejsc postojowych, w tym dla pojazdow zaopatzanych w katę parkingowa, zgodnile ustaleriami ş18,

p) dopuszoza slę drog wewnętzule o szerokosd pasa drogowego nie mriejszel niz $8,0 \mathrm{~m}, \mathrm{z}$ dopuszazenlem sytuowanla budynkow w odlegosd co najmmle\} $5,0 \mathrm{~m}$ od granicy pasa drogowego drog wewnęture,

q) obstuqa komunkacyna $\mathrm{z}$ đoq $41 \mathrm{KDO}$.

Rys. 1. Zapisy planistyczne na przykładzie aktualizowanego MPZP Kołobrzeg-Wschód dla terenu 29 UZ

Źródło: projekt zmiany MPZP, Kołobrzeg 2016

Analizę progową można przeprowadzić opierając się na podstawowych miernikach i wskaźnikach urbanistycznych ujmowanych w MPZP, tj: 


$$
\text { In }=\frac{P o g}{T n} \quad k=\frac{P o g}{P z a b} \quad G z a b=\frac{P z a b}{T n}=\frac{I n}{k}
$$

gdzie:

In - intensywność zabudowy (powierzchnia ogólna budynków do powierzchni terenu),

$k$ - średnia ważona liczba kondygnacji (wysokość zabudowy według liczby kondygnacji),

Gzab - gęstość zabudowy (procentowy udział powierzchni zabudowy w powierzchni działki),

Pzab - powierzchnia zabudowy (powierzchnia terenu zajęta pod zabudowę wyrażana w \%),

Pog - powierzchnia ogólna (suma powierzchni wszystkich kondygnacji mieszkalnych),

Tn - powierzchnia terenu inwestycji (dawniej netto lub powierzchnia nieruchomości).

Wskaźnik intensywności zabudowy może dostarczyć pośrednio wiedzy o przewidywanej gęstości zaludnienia. Zakładając wskaźnik powierzchni ogólnej na 1 mieszkańca (Wm) można oszacować liczbę ludności na danym terenie i gęstość zaludnienia:

$$
L m=\frac{P o g}{W m} \quad G m=\frac{L m}{T n}=\frac{I n}{W m} .10000\left[\frac{\text { l.osób }}{1 h a}\right]
$$

gdzie:

Lm - liczba mieszkańców,

Wm - wskaźnik Pog/1 mieszkańca (dawniej 20 m²/osobę, obecnie $30 \mathrm{~m}^{2}$ /osobę),

$\mathrm{Gm}$ - gęstość zaludnienia.

Na potrzeby studialne i obliczeń niniejszego opracowania przyjęto założenia, że: $W m=30 \mathrm{~m}^{2} /$ osobę, 2,5 osoby/1 lokal, 1 m.p. $\left(25 \mathrm{~m}^{2}\right) / 1$ lokal, zaś dla planu $I n=$ od 0,45 do 3,0, Pzab $=45 \%$, Pziel $=50 \%, k=5,2$ kondygnacje podziemne, miejsca parkingowe zgodnie $\mathrm{z}$ planem (zewnętrzne $\mathrm{w}$ zespołach do 50 miejsc, podziemne lub wielokondygnacyjne według MPZP).

Powierzchnia terenu (Tn) 29UZ wynosi 1,5414 ha (15 $\left.414 \mathrm{~m}^{2}\right)$, co przy wskaźniku Pzab $=45 \%$ pozwala na uzyskanie Pzab $=6936 \mathrm{~m}^{2}$, co przy 5 kondygnacjach daje $P o g=34681 \mathrm{~m}^{2}$. Zatem przy założeniu $W m=30 \mathrm{~m}^{2} /$ osobę Lm osiąga 1387 osób. Intensywność zabudowy wyniesie $I n=2,24(34681$ m² 
$\left.15414 \mathrm{~m}^{2}\right)$. Średnia liczba kondygnacji $k=5\left(\operatorname{Pog} 34681 \mathrm{~m}^{2} /\right.$ Pzab $\left.6936 \mathrm{~m}^{2}\right)$. Maksymalna gęstość zaludnienia może sięgnąć $G m=900$ osób/ha ( $L m$ 1387) $T n=1,5414 \mathrm{ha}$ ). Według zapisu planu przy $W m=25$ dla terenu $28 \mathrm{UZ}$ przyjęto zaludnienie $\mathrm{w}$ przedziale od 180 do 1200 osób/ha (od 0,45 do 3,0/ $25 \cdot 10000$ ), zatem obliczone $L m$ wynoszące 900 osób/ha mieści się w górnych zapisach $W m$ do 1200 osób/ha.

Zakładając zastosowanie przez inwestorów tzw. zielonych dachów można zwiększyć Pzab z 45\% do 67,5\%, co oznacza, że Pzab $=10404 \mathrm{~m}^{2}$, a przy $k=5$ pozwoli teoretycznie osiągnąć $\operatorname{Pog}=52000 \mathrm{~m}^{2}$, czyli $I n=3,37$, co $\mathrm{z}$ kolei jest przekroczeniem zapisów planu. A zatem po koniecznej korekcie, dla In = 3,0 możliwa Pog = $46242 \mathrm{~m}^{2}$. Pog 46 242/Wm $30 \mathrm{~m}^{2}=1541$ osób, czyli 1000 osób/ha, a przy $W m=25 \mathrm{~m}^{2}$ i Pog $=46242 \mathrm{~m}^{2}$ dopuszczalne zaludnienie wyniesie 1849 osób, czyli 1200 osób/ha. Z tego wynika, że wartości zaludnienia na badanym terenie 29UZ mieszczą się w zakresie od 200 do 1200 os/ha (przy In w zakresie 0,45-3,0).

Przeprowadzone symulacyjne obliczenia wskaźników i mierników urbanistycznych pozwalają wskazać skalę procesów kolonizacyjnych lub urbanizacyjnych zachodzących $\mathrm{w}$ przestrzeni turystycznej, określając minimalne i maksymalne progi przemian przestrzeni turystycznej (standardy) w stosunku do istniejącego już zagospodarowania turystycznego.

Ustalone mierniki i współczynniki urbanistyczne zawarte w studium uwarunkowań i zagospodarowania przestrzennego oraz w miejscowych planach zagospodarowania przestrzennego są kluczowe dla realizacji wielu inwestycji. Cechą szczególną jest co najmniej kilkuletni, a zwykle kilkunastoletni okres ich obowiązywania, dzięki czemu zapisy te mogą być w pełni wykorzystane $\mathrm{w}$ analizie przemian przestrzeni turystycznej.

Zatem chcąc określić, czy dany obszar będzie rozwijał swoje zagospodarowanie turystyczne, należy dokonać szczegółowej analizy zapisów planistycznych i ustalić, czy pod względem przestrzennym i urbanistycznym są rezerwy rozwojowe i czy istniejące warunki mikroekonomiczne i makroekonomiczne pozwolą na realizację nowych inwestycji. Jeśli uzyskane odpowiedzi w fazie analiz rozwoju progowego będą pozytywne, można liczyć na faktyczny rozwój i zagospodarowanie nowych przestrzeni pod działalność turystyczną.

Wskazane mierniki i współczynniki urbanistyczne stosowane w celu ustalania progów rozwoju przestrzeni turystycznej mogą pomóc w wyznaczaniu optymalnych lokalizacji nowych przestrzeni turystycznych lub przebudowy już istniejących. $\mathrm{W}$ wielu przypadkach elementem determinującym 
realizację nowych inwestycji, obok zasobów terenowych i korzystnych zapisów planistycznych, jest także wartość i lokalizacja nieruchomości. Indywidualne warunki środowiskowe, geologiczne, wodne, gruntowe i ochrony walorów środowiskowych również wyznaczają próg opłacalności rozpoczęcia działań zmierzających do zmiany funkcji danego terenu.

Ważnym elementem jest także cena zakupu danego terenu lub posiadanie już danego terenu jako zabezpieczenia rynkowego dla danej inwestycji w przypadku starania o kredytowanie lub pozyskanie innego kapitału zewnętrznego. Dla rozpatrywania możliwości inwestycji w Polsce istotne są zapisy studium uwarunkowań i kierunków zagospodarowania przestrzennego danej gminy oraz zapisy dla przygotowywanego lub już uchwalonego i obowiązującego miejscowego planu zagospodarowania przestrzennego.

Prowadząc ustalenia możliwości przemian przestrzeni turystycznej należy uwzględnić także wymagania i ograniczenia środowiskowe, geologiczne, ochrony walorów przyrodniczych czy istotne ograniczenia inwestycyjne wynikające z innych aktów i przepisów prawnych. Powinno się brać też pod uwagę dostępność mediów i infrastruktury technicznej oraz możliwości przyłączeniowe do istniejącej lub projektowanej infrastruktury. W przypadku dużych inwestycji konieczne mogą być także znaczące nakłady na przebudowę, np. układu komunikacyjnego, czy konieczność budowy parkingów buforowych lub innych sieciowych, albo przestrzennych obiektów towarzyszących (np. autostrada).

Ostatnim kluczowym elementem, jaki powinien być dokładnie ustalony w przypadku analiz progowych rozwoju obszarów turystycznych, jest skala i poziom rozwoju danej przestrzeni turystycznej w okresie poprzedzającym ustalanie perspektyw dalszego przebiegu cyklu życia obszaru turystycznego (liczba łóżek, pojemność bazy noclegowej, obłożenie bazy noclegowej, liczba udzielanych osobonoclegów, zużycie wody, odpady itp.).

$W$ ramach otoczenia makroekonomicznego niezbędne jest ustalenie możliwości wykonawczych, a następnie zarządczych istniejące w lokalnej gospodarce, przebiegu cyklu koniunkturalnego, struktury rynku, a nawet sytuacji prawnej, podatkowej i politycznej w kraju.

Szczegółowe analizy możliwości rozwojowych na poziomie planistycznym i inwestycyjnym mogą dać odpowiedź, czy dany teren będzie mógł przekształcić się w przestrzeń turystyczną lub czy już istniejący obszar przestrzeni turystycznej będzie rozwijał się dalej, czy popadnie w stagnację, a nawet czy zagrozi mu upadek. 


\section{Teoria progowa a cykl życia obszaru turystycznego (TALC)}

W wielu pracach naukowych dotyczących rozwoju przestrzeni turystycznej zwrócono uwagę na sytuację, gdy dany obszar turystyczny cechuje bardzo długi cykl życia. Mamy wówczas problem wyznaczenia faktycznego przebiegu cyklu życia obszaru turystycznego, gdyż w krótkim przebiegu cyklu można wywnioskować, że już wystąpiło załamanie rozwoju i „ogłaszamy” okres recesji, a nawet „upadku”, podczas gdy przy bardzo długim cyklu życia obszaru turystycznego wystąpiło krótkotrawałe, kilkuletnie spowolnienie czy zatrzymanie wzrostu danego obszaru turystycznego. Zasada ta przypomina przebieg wielkich cykli koniunkturalnych $w$ ekonomii, jednak $w$ niej opieramy się na dość abstrakcyjnych wartościach ekonomicznych, a w przypadku obszaru turystycznego mamy realną wartość ekonomiczną i realne zagospodarowanie turystyczne, $\mathrm{w}$ ramach którego funkcjonuje ruch turystyczny.

Być może klasyczny teoretyczny cykl życia obszaru turystycznego o wyjątkowych walorach turystycznych można porównywać do cykli życia i wzrostu wartości rzadkich dóbr luksusowych w określonym momencie ich wyceny, a im dany produkt turystyczny czy obszar turystyczny reprezentuje cenniejsze walory, tym teoretycznie większą wartość wzrostu cyklu życia powinien osiągnąć. Wyjątkowo rzadki, szczególnie cenny i bardzo pielęgnowany obszar turystyczny, jako produkt turystyczny będący fragmentem przestrzeni turystycznej można zatem traktować jak absolutny unikat, co skutkuje teoretycznie brakiem możliwości ustalenia docelowego, „szczytowego" przebiegu cyklu życia i wartości docelowej. Może być on zatem nawet bezcenny, ti. np. ostatni w skali kontynentu obszar o naturalnych walorach przyrodniczych. Podobnie jak niemożliwe jest zawczasu ustalenie „cyklu życia" cennego diamentu, tak niezwykle trudne jest ustalenie przebiegu dalszego cyklu życia wybranego obszaru turystycznego, a zatem jeszcze trudniejsze jest ustalenie, na którym etapie TALC znajdzie się dany obszar za kilka lat.

Jeśli nie można precyzyjnie przewidzieć przyszłości cyklu życia obszaru turystycznego opierając się tylko na podstawie jego przebiegu w przeszłości, należy szukać możliwości ustalenia przeszłego i przyszłego cyklu życia obszaru turystycznego za pomocą narzędzia, jakim jest metoda analizy progowej oparta na dokumentach planistycznych oraz szczegółowej wycenie ryn- 
kowej i możliwych do osiągnięcia wskaźnikach i miernikach skali zagospodarowania turystycznego danego obszaru turystycznego.

Ocenę skali i jakości zagospodarowania turystycznego danego obszaru turystycznego można zatem przyrównać do oceny sposobu wykonania szlifu i jakości wypolerowania kamienia szlachetnego, zaś zanieczyszczenia środowiskowe czy utratę części walorów turystycznych dla danego obszaru turystycznego czy przestrzeni turystycznej można z kolei porównać do wystąpienia skazy lub rysy w kamieniu szlachetnym. Wskazane cechy dodatnie i ujemne dla każdego ze wskazanych obiektów skutecznie obniżają lub podnoszą wartość ich obu, czyli pośrednio wskazują, czy będzie dalszy przyrost czy jednak spadek ich wartości.

Przeprowadzenie szczegółowej oceny badanego obszaru turystycznego stanowiącego fragment przestrzeni turystycznej według założeń teorii progowej pozwala z kolei wskazać najbardziej prawdopodobny przebieg cyklu życia tej przestrzeni, a korzystając z klasycznych mierników i wskaźników urbanistycznych oraz założeń czasu realizacji planowanych przedsięwzięć inwestycyjnych pozwoli wyznaczyć horyzont czasowy.

Prawidłowo przeprowadzona analiza progowa przestrzeni turystycznej oparta na analizie mierników i wskaźników urbanistycznych oraz pomocniczo mierników inwestycyjnych może pozwolić na określenie prawdopodobnego przebiegu przyszłego TALC. Analiza TALC z ustaleniem cykli rozwojowych oraz wyznaczeniem kluczowych progów i okresów przemian (rozwoju, stagnacji czy regresu cyklu) stanowi drogę do uzyskania danych wejściowych do wskazania skali, czasu i możliwości realizacji inwestycji na danym obszarze, a co za tym idzie teoretycznego przebiegu perspektywicznego TALC. Należy przy tym zauważyć, że narzędzie w postaci analiz progowych można zastosować zarówno dla niewielkich obszarów objętych przekształceniami przestrzeni turystycznej, jak i dla całych miejscowości oraz regionów turystycznych na zasadzie zastosowania sum proponowanych i realizowanych przedsięwzięć inwestycyjnych w stosunku do ogólnego potencjału danego obszaru turystycznego - przestrzeni turystycznej z uwzględnieniem elementów planistycznych i funkcjonalnych (CIBOROWSKI 1980).

Ustalony na podstawie wielu lat badań przebieg cyklu życia obszaru turystycznego dla miasta - uzdrowiska Kołobrzeg, pozwolił wskazać trzy bardzo wyraźnie zaznaczające się okresy - etapy - fazy cyklu życia tego obszaru (MIEDZIŃSKI 2013b) (rys. 2). 
Obok dotychczasowych mierników zawierających liczbę miejsc noclegowych, liczbę osobonoclegów czy powierzchnię użytkową bazy noclegowej można wykorzystać wiele wspomnianych wcześniej mierników i wskaźników urbanistycznych, które pozwalają wyznaczyć potencjalną skalę proponowanych i możliwych do realizacji inwestycji, a w końcu rzeczywistych przekształceń przestrzeni turystycznej.

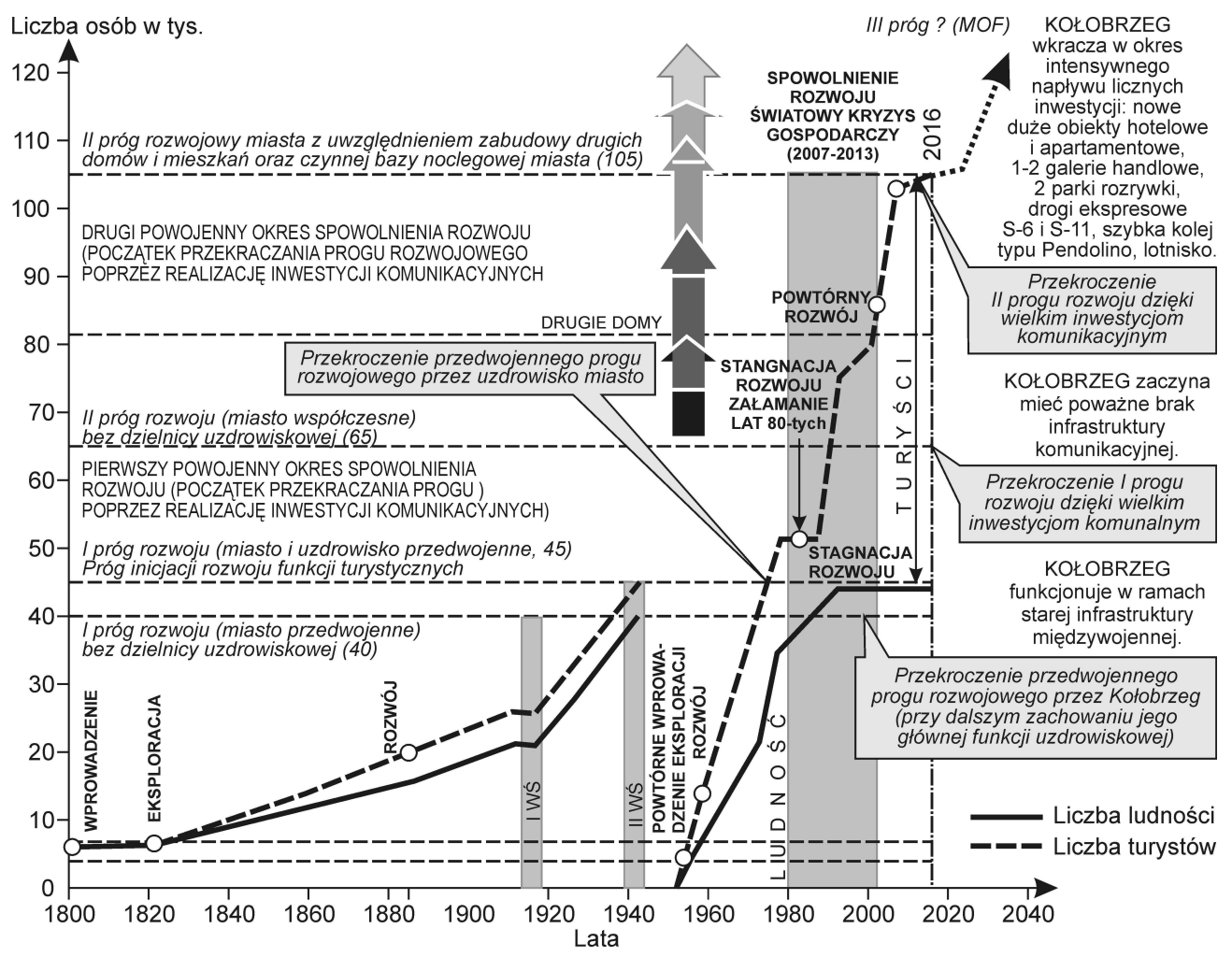

Rys. 2. Progowy cykl życia obszaru turystycznego (TTALC) dla Kołobrzegu w latach 1800-2040 uwzględniający ludność, drugie domy i mieszkania oraz bazę noclegową

Źródło: opracowanie własne

W przypadku powojennego rozwoju Kołobrzegu można zatem wyróżnić:

- I powojenny okres intensywnego rozwoju (1958-1979), etap odbudowy Kołobrzegu;

- I powojenny okres spowolnienia rozwoju (1980-1989), przekraczanie I progu rozwoju; 
- II powojenny okres intensywnego rozwoju (1990-2007), pokonanie I progu rozwoju;

- II powojenny okres spowolnienia rozwoju (2008-2010), przekraczanie II progu rozwoju;

- wejście w III powojenny okres intensywnego rozwoju (od 2011), utworzenie miejskiego obszaru funkcjonalnego (MOF).

Na podstawie powyższych rozważań można wskazać przebieg progowego TALC (rys. 3).

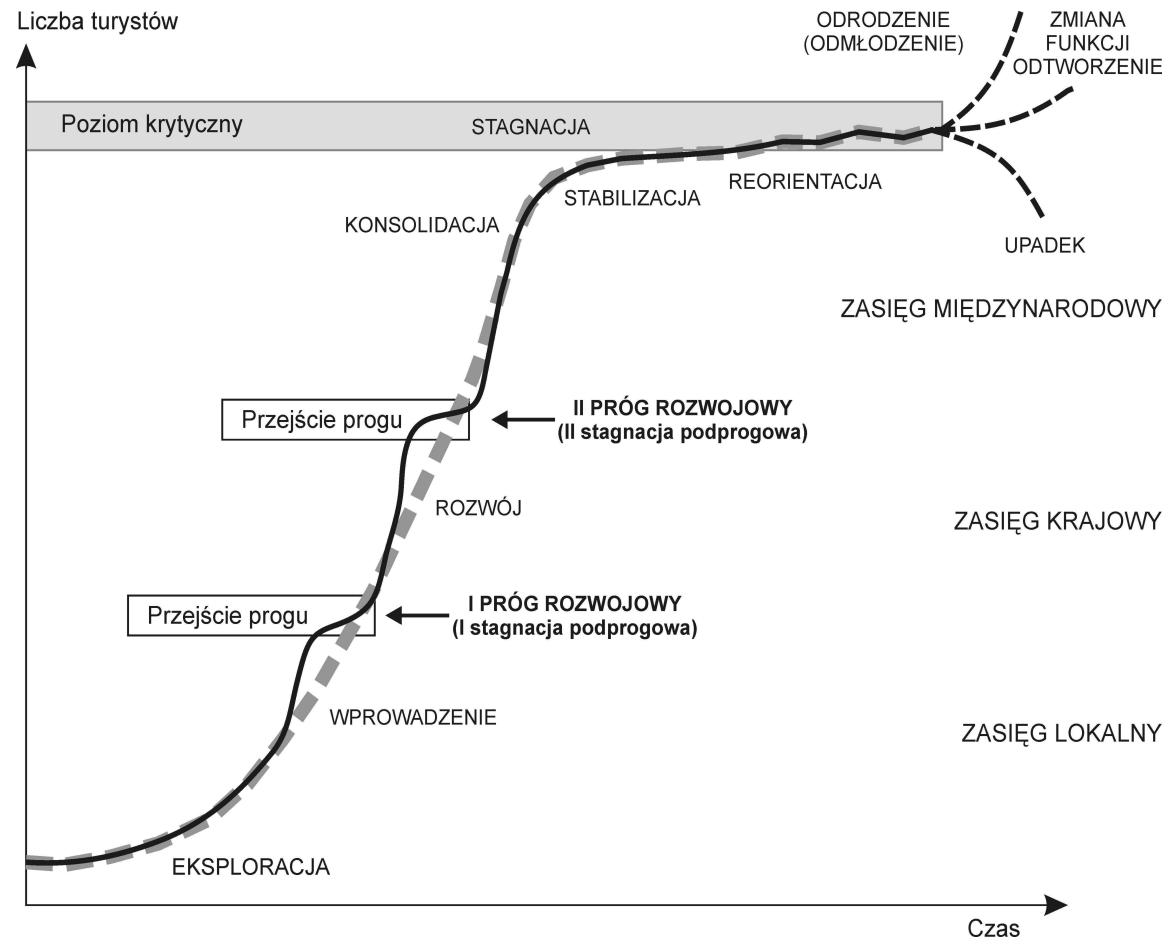

Rys. 3. Klasyczny zmodyfikowany progowy cykl życia obszaru turystycznego według R.W. Butlera z późniejszymi zmianami wprowadzanymi przez innych autorów Źródło: opracowanie własne na podstawie R.W. Butler (2011, s. 33)

Badania nad przestrzenią turystyczną i cyklem życia obszarów turystycznych (TALC) powinny zatem uwzględniać problematykę progów rozwojowych. Należy przeprowadzić pogłębioną analizę możliwości zastosowania metody progowej jako wspomagającego narzędzia analitycznego 
opartego na podstawowych analizach przestrzennych i urbanistycznych z wykorzystaniem typowych dla planowania przestrzennego mierników i wskaźników urbanistycznych. Wyznaczenie możliwości rozwojowych obszaru turystycznego w oparciu o klasyczne analizy przestrzenne i urbanistyczne, a następnie nałożenie otrzymanych wyników możliwych wariantów przekształceń na dotychczasowy potencjał turystyczny pozwoli na ustalenie progów rozwojowych i przebiegu hipotetycznego perspektywicznego TALC. Jeśli dysponujemy historyczną i obecną liczbą miejsc noclegowych, powierzchnią użytkową obiektów turystycznych, stopniem wykorzystania miejsc noclegowych oraz liczbą udzielonych osobonoclegów, można dodać dane pozyskane $\mathrm{w}$ wyniku zastosowania metody analizy progowej i w ten sposób ustalić cykl życia obszaru turystycznego w przeszłości i jego przebieg według perspektywy planistycznej wyznaczonej przyjętymi wskaźnikami i miernikami urbanistycznymi.

\section{Wskazania przestrzenne i planistyczne do zastosowania teorii progowej}

Kołobrzeg cechuje się dość dobrze poznanym przebiegiem cyklu życia obszaru turystycznego (TALC), zachowano tu jednocześnie walory uzdrowiskowe i środowiskowe, a gospodarkę charakteryzuje systematyczny napływ inwestycji (MIEDZIŃSKI 2011, 2012). Kluczowe jest tu prowadzenie gospodarki przestrzennej opartej na miejscowych planach zagospodarowania przestrzennego ze wskazaniem preferowanych obszarów rozwoju funkcji turystycznych, w ramach których szczególnie uwzględnia się zabudowę związaną $\mathrm{z}$ turystyczną bazą noclegową oraz zabudowę mieszkaniową drugich domów, mieszkań i apartamentów.

Według stanu na koniec 2015 roku na obszarze Nadmorskiego Obszaru Funkcjonalnego (NOF) Kołobrzeg znajdowało się ponad 28000 lokali mieszkalnych liczących ponad 113000 izb o łącznej powierzchni użytkowej około $2200000 \mathrm{~m}^{2}$. Liczba miejsc noclegowych $\mathrm{w}$ różnorodnej turystycznej bazie noclegowej przekroczyła 100000 łóżek. Oficjalna liczba osobonoclegów osiągnęła 3750 000, natomiast nieoficjalnie - jak wynika z badań - wielkość ta zbliżyła się do 12000 000, co jest porównywalne z Benidormem (Hiszpania) czy Portimao (Portugalia). Na podstawie zapisów studium uwarunkowań i kierunków zagospodarowania przestrzennego oraz uchwalonych i obowią- 
zujących miejscowych planów zagospodarowania przestrzennego możliwe jest ustalenie rezerw rozwojowych w zakresie zabudowy mieszkaniowej (drugie domy i apartamenty) oraz rezerw terenowych pod zabudowę o charakterze turystycznym łącznie z określeniem progów rozwojowych. Dotyczy to także zasobów przestrzennych w przygotowywanych i opracowywanych dokumentach planistycznych. Na podstawie aktualnego wykazu projektowanych, przygotowywanych i realizowanych inwestycji możliwe jest ustalenie aktualnego przyrostu zasobów bazy noclegowej, a przy uwzględnieniu jej zróżnicowania i stopnia wykorzystania w poszczególnych okresach możliwe jest określenie skali i kierunków zmian poszczególnych mierników oraz wskaźników funkcjonowania obiektów turystycznych w przestrzeni turystycznej NOF Kołobrzeg. Wykazane zmiany wielkości potencjału turystycznego na podstawie wskaźników i mierników urbanistycznych, dzięki zastosowaniu teorii progowej Malisza, pozwalają z kolei na wyznaczenie przebiegu trendu rozwojowego, a następnie ustalenie przebiegu cyklu życia obszaru turystycznego Kołobrzegu w perspektywie najbliższych kilku lat. Uzyskane $\mathrm{w}$ ten sposób modelowanie rozwoju jest obarczone pewnymi ograniczeniami zewnętrznymi (możliwości inwestycyjne inwestorów, sytuacja ekonomiczna kraju i gospodarki, inflacja, sytuacja polityczna, cykl koniunkturalny, decyzje polityczne i fiskalne itp.), jednak dla kierunków przemian NOF Kołobrzeg kluczowe jest kompleksowe planowanie przestrzeni turystycznej i docelowej pojemności projektowanej, budowanej i działającej bazy noclegowej przy zachowaniu zasad zrównoważonego rozwoju i utrzymaniu zasobów balneologicznych i uzdrowiskowych.

W latach 2016-2020 planowana i przygotowywana jest realizacja kilku dużych inwestycji hotelowych obliczanych na ponad 2000 pokoi hotelowych z 4000 miejsc o łącznej powierzchni użytkowej obiektów hotelowych przekraczającej $100000 \mathrm{~m}^{2}$. Obok tego w budowie znajduje się ponad 1000 mieszkań i apartamentów, a do realizacji szykowane są dalsze inwestycje liczące około 1500 lokali. Łączna pojemność noclegowa projektowanej i realizowanej bazy noclegowej wraz z drugimi mieszkaniami i apartamentami zwiększy dotychczasowe zasoby o ponad 10\% (ponad 6000 łóżek), co przy założeniu dalszej poprawy stopnia wykorzystania bazy noclegowej z poziomu około $66 \%$ do $70 \%$ pozwoli zwiększyć liczbę oficjalnie odnotowywanych osobonoclegów o około 500000 do poziomu około 4500000 rocznie. Nieoficjalnie odnotowywana liczba osobonoclegów może zbliżyć się do $13 \mathrm{mln}$. Sygnalizuje to istotną poprawę odnotowywanych mierników ruchu turystycznego i stanowi istotne potwierdzenie kierunku wzrostowego cyklu życia obszaru 
turystycznego miasta Kołobrzeg i NOF Kołobrzeg (MIEDZIŃSKI 2011, 2012, 2013a, b).

Prowadzone badania mają na celu powtórne odrodzenie praktycznego zastosowania teorii progowej Malisza i Kozłowskiego do prognozowania przekształceń miejscowości i regionów turystycznych oraz zaadaptowania założeń metodologicznych tej teorii do ustalania wielkości progowych perspektywicznego przebiegu wykresu TALC według Buttlera czy progów sygnalizujących etapy rozwoju przestrzeni według Liszewskiego (asymilacja, kolonizacja, urbanizacja) i Włodarczyka (przestrzeń nowa, dojrzała, stara). Intensywny rozwój NOF Kołobrzeg, tworzącego największy turystyczny zespół osadniczy na polskim wybrzeżu obok Trójmiasta, umożliwia kompleksowe przeprowadzenie badań przemian nadmorskiej przestrzeni turystycznej Polski w skali porównywalnej tylko do najsilniej rozwiniętych i zagospodarowanych odcinków nadmorskiej przestrzeni turystycznej południowej i zachodniej Europy.

\section{Bibliografia}

AGARWAL S., 2002, Restructuring seaside tourism the resort lifecycle, "Annals of Tourism Research", 29, 1, s. 25-55.

BUTLER R.W., 1980, The concept of a tourist area life cycle of evolution: implications for management resources, "Canadian Geographer", 24, 1, s. 5-12.

ButLER R.W., 2011, Tourist Area Life Cycle, "Contemporary Tourist Reviews”, Oxford, OX3 9TJ.

CiBOROWSKI A., 1980, Międzynarodowe zadania planisty przestrzennego (notatka refleksyjna o Bolestawie Maliszu), „Przegląd Geograficzny”, LII, 3, s. 485-494.

DURYDIWKA M., DUDA-GROMADA K., 2011, Przestrzeń turystyczna. Czynniki, różnorodność, zmiany, Uniwersytet Warszawski, Wydział Geografii i Studiów Regionalnych, Warszawa, 456 ss.

DZIEWOŃSKI K., 1980, Na siedemdziesięciolecie Bolestawa Malisza, „Przegląd Geograficzny”, LII, 3, s. 481484.

EBERHARD P., 1980, Metody planowania układów osadniczych, „Przegląd Geograficzny”, LII, 3, s. 519-541.

LISZEWSKI S., 1995, Przestrzeń turystyczna, „Turyzm”, 5, 2, s. 87-103.

MALISZ B., 1971, Metoda analizy progowej w zastosowaniu do planowania miast i regionów, „Studia KPZK PAN", XXXIV, s. 5-111.

MIEDZIŃSKI M., 2011, Kołobrzeg jako centrum turystyki uzdrowiskowo-wypoczynkowej po 20 latach przemian ustrojowych (1989-2009), [w:] Turystyka polska w latach 1989-2009, ser. „Warsztaty z Geografii Turyzmu", Wyd. Uniwersytetu Łódzkiego, Łódź.

MIEDZIŃSKI M., 2012, Miasto Kotobrzeg wiodącym uzdrowiskiem Polski i jednym z centrów turystycznych kraju, [w:] E. Rydz (red.), Ekonomiczne i organizacyjne aspekty funkcjonowania polskich uzdrowisk, Wyd. Akademii Pomorskiej, Słupsk, s. 139-150.

MIEDZIŃSKI M., 2013a, Uzdrowisko Kotobrzeg w świetle zmodyfikowanego cyklu życia obszaru turystycznego R.W. Butlera oraz teorii progowej B. Malisza, [w:] Turystyka uzdrowiskowa w gospodarce regionów, "Zeszyty Naukowe Uniwersytetu Szczecińskiego”: Ekonomiczne problemy turystyki, Wyd. Naukowe Uniwersytetu Szczecińskiego, Szczecin, s. 209-224. 
MIEDZIŃSKI M., 2013b, Modyfikacja cyklu życia obszaru turystycznego (TALC) w wyniku wprowadzenia założeń teorii progowej na bazie przestrzeni turystycznej Kołobrzegu i jego zaplecza, [w:] R. Jaroszewska-Brudnicka, D. Sokołowski (red.), Współczesne problemy rozwoju turystyki w ujęciu regionalnym i lokalnym, Wyd. Naukowe UMK, Toruń, s. 213-228.

REGULSKI J., WYGANOWSKI S., 1965, Próba ekonomicznej interpretacji teorii progóww, „Biuletyn JUA”, s. 2021.

WŁODARCZYK B., 2009, Przestrzeń turystyczna. Istota, koncepcje, determinanty rozwoju, Wyd. Uniwersytetu Łódzkiego, Łódź, 268 ss.

WŁODARCZYK B., 2011, Przestrzeń turystyczna - kilka stów o istocie pojęcia, [w:] M. Durydiwka, K. Duda-Gromada (red.), Przestrzeń turystyczna. Czynniki, różnorodność, zmiany, Uniwersytet Warszawski, Wydział Geografii i Studiów Regionalnych, Warszawa, s. 15-28. 